Hikmah: Journal of Islamic Studies, 16 (2), 2020, 121-142

http://journal.uinjkt.ac.id/index.php/HIKMAH

DOI: 10.47466/hikmah.v16i2.171 | P-ISSN. 2088-2629, E-ISSN. 2581-0146

\title{
HUKUM TALAQ ISTERI KETIKA HAIDH: SATU ANALISIS HADITH DAN FIQH
}

\author{
Nabilah Yusof \\ Universiti Sains Islam Malaysia \\ nabilah@usim.edu.my
}

\begin{abstract}
This article deals with the divorce occurred during the wife's menstrual period. It aims to examine the status of hadiths on the law of divorce during the wife's menstrual period and also the opinion of fiqih madhab on it. The research is library research with analysis and descriptive method. Some hadiths on it are analyzed with takhrij method, either the text of hadith or the chains of transmitter (sanad). The article also analyses the opinion of fiqh scholars on the law of divorce during the wife's menstrual period. Based on shariah, the divorce is allowed if the husband divorce the wife in nonmenstrual and before having a sexual intercourse. But if the divorce occurred during the wife's menstrual period, there are many opinions among ulama. The result of this research shows that majority ulama stated it is unlawful if if the husband divorce the wife during her menstrual period, and his divorce is unlawful. But, Ibnu Qayyim al-Jauziyyah said that the divorce is not in line with shariah and unlawful and the husband is regarded sin doer.
\end{abstract}

Keywords: Divorce; Wife; Menstrual

\begin{abstract}
Abstrak
Artikel ini adalah berkaitan dengan Talak Isteri Ketika Haidh. Penulisan ini bertujuan untuk meneliti status hadis-hadis berkaitan hukum talak isteri ketika haidh serta pandangan mazhab figh mengenainya. Jenis penelitian yang digunakan adalah penelitian kepustakaan (library research) dengan menggunakan metode deskriptif-analisis. Penulis menganalisis hadis-hadis tersebut melalui kaedah takhrij (redaksi) hadis yaitu, analisis matan (teks) dan sanad hadis seterusnya meneliti pandangan para fuqaha sekitar hukum talak ketika isteri dalam keadaan haidh. Menurut hukum syarak, talak sah apabila suami menceraikan isteri pada saat isteri dalam keadaan suci yang sebelumnya tidak digauli. Namun jika talak dijatuhkan saat isteri dalam keadaan Haidh, antara jumhur dan Ibn Qayyim al-Jauziyyah serta beberapa fuqaha berbeda pandangan. Hasil penelitian menunjukkan bahwa menurut jumhur ulama, hukum suami yang mentalak isteri ketika Haidh adalah haram dan hukum talaknya adalah sah. Namun, menurut Ibnu Qayyim al-Jauziyyah, talak tersebut tidak disyariatkan dan talak yang dijatuhkan tidak sah, serta suami tetap dianggap telah berdosa.
\end{abstract}

Kata Kunci: Talak; Isteri; Haidh 


\section{PENDAHULUAN}

Setiap perkara dalam kehidupan ini samada kecil atau besar, ada aturan dan tatasusila serta adab yang telah ditentukan oleh Allah swt dan harus dipatuhi oleh setiap hamba. Apatahlagi dalam perkara yang melibatkan mu'amalah (hubungan) antara manusia dengan manusia, antaranya perkara yang melibatkan perkahwinan dan perceraian.

Dalam hukum keluarga, atau lebih tepatnya pada bidang hukum perkahwinan, digambarkan bahwa seorang suami dan isteri wajib untuk mempertahankan kelestarian dari hubungan perkahwinannya. Dikatakan demikian mengingat hubungan tersebut sebagai suatu ikatan yang sakral (suci), ikatan yang kuat, atau dalam istilah lain disebut sebagai "mitsaqan ghalizhan".

Oleh kerana ikatan suci itu, Allah swt membenci ketika hubungan tersebut harus putus atau cerai. Meski demikian, kedudukan hukum cerai tetap diperbolehkan dalam agama dengan memperhatikan ketentuan syariat Islam. ${ }^{2}$

Suatu yang wajar ketika hubungan perkahwinan tidak harmonis. Akan tetapi, jika ketidakharmonian hubungan tersebut tidak dapat disikapi secara baik, ini akan memiliki implikasi dan berhujung pada terjadinya talak. Kecenderungan suami dalam mempertahankan sikap peribadi (ego) berakibat pada tidak terselesaikannya masalah dalam keluarga, begitu pula halnya yang berlaku pada seorang isteri. Seluruh ulama fiqh sepakat (konsensus atau berijma) bahwa perceraian antara suami isteri diperbolehkan. ${ }^{3}$

Terhadap adanya hukum legal suatu perceraian atau talak, di dalamnya diatur pula mengenai tata cara bagaimana seharusnya talak itu dilaksanakan menurut tuntunan syari'at. Walaupun perceraian itu adalah suatu perkara yang paling dibenci dan dimurkai oleh Allah swt menurut hadis nabi saw, namun dari sudut hukum keluarga ianya adalah sah sekiranya memenuhi syarat-syarat sah pembubaran perkahwinan (perceraian).

Antara adab atau aturan suatu perceraian yang ditetapkan oleh Allah swt, hendaklah suatu perceraian itu dilakukan ketika isteri dalam keadaan suci daripada haidh. Ini bertepatan dengan firman Allah swt:

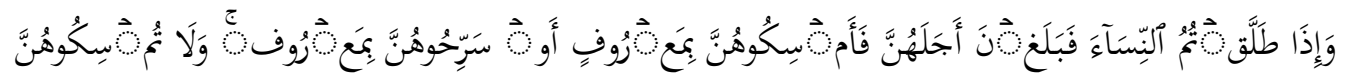

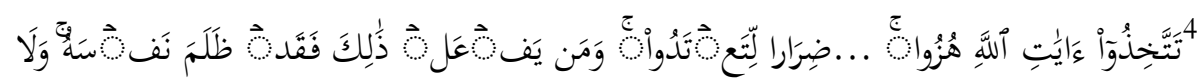

\footnotetext{
${ }^{1}$ Citra Umbara, Undang-Undang Republik Indonesia Nomor 1 Tahun 1974 Tentang Perkahwinan dan Kompilasi Hukum Islam, (Cet. V, Bandung: Citra Umbara, 2014), h. 352.

${ }^{2}$ Hamid Sarong, Hukum Perkahwinan Islam di Indonesia, (Cet. III, Banda Aceh: Yayasan PeNA, 2010), h. 118 189.

${ }^{3}$ Abdul Majid Mahmud Mathlub, al-Wajis fi al-Ahkam al-Islamiyah; Panduan Hukum Keluarga Sakinah, (terj: Harits Fadly, Ahmad Khotib), (Surakarta: Era Intermedia, 2005), h. 314

${ }^{4}$ Surah al-Baqarah [1]: 231
} 
Artinya: "Apabila kamu mentalak isteri-isterimu, lalu mereka mendekati akhir iddahnya, maka rujukilah mereka dengan cara yang ma'ruf, atau ceraikanlah mereka dengan cara yang ma'ruf (pula). Janganlah kamu rujuki mereka untuk memberi kemudharatan, kerana dengan demikian kamu menganiaya mereka. Barangsiapa berbuat demikian, maka sungguh ia telah berbuat zalim terhadap dirinya sendiri. Janganlah kamu jadikan hukum-hukum Allah permainan...”.

Ada dua perkara utama berkaitan talak atau perceraian yang Allah swt zahirkan di dalam ayat tersebut iaitu ma'ruf dan dhirar. Walaupun kuasa talak itu diberikan oleh Allah swt ke atas kaum suami, namun dalam masa yang sama Allah swt perintahkan mereka agar berlaku ma'ruf serta menghindari kemudharatan ke atas kaum isteri dengan mendatangkan aturan dalam perceraian yang perlu dipatuhi oleh suami. Aturan tersebut bertujuan memelihara maslahah (kebajikan) isteri yang akan diceraikan iaitu dicerai secara ma'ruf ketika isteri dalam keadaan suci daripada haidh dan menghindari dhirar (kemudharatan) dengan tidak menceraikan isteri dalam keadan haidh. Sesungguhnya hikmah mengapa Allah mendatangkan aturan ini, terkandung dalam firman Allah swt yang berikut:

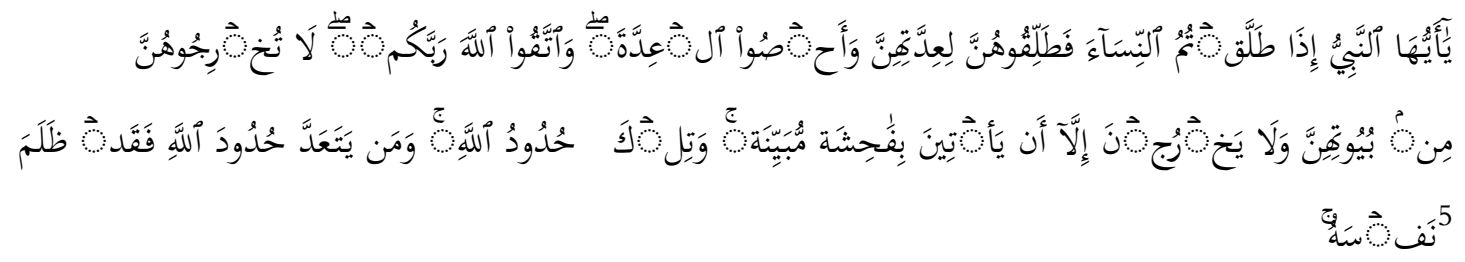

Artinya: "Hai Nabi, apabila kamu menceraikan isteri-isterimu maka hendaklah kamu ceraikan mereka pada waktu mereka dapat (menghadapi) iddahnya (yang wajar) dan hitunglah waktu iddah itu serta bertakwalah kepada Allah Tuhanmu. Janganlah kamu keluarkan mereka dari rumah mereka dan janganlah mereka (diizinkan) ke luar kecuali mereka mengerjakan perbuatan keji yang terang. Itulah hukum-hukum Allah dan barangsiapa yang melanggar hukum-hukum Allah, maka sesungguhnya dia telah berbuat zalim terhadap dirinya sendiri..."

Ayat di atas dipahami bahwa keadaan dimana suami yang akan menceraikan isterinya harus melihat waktu bagi isteri dapat menghitung dan menghadapi masa menunggu atau iddah, keadaan tersebut seperti tidak menjatukan talak pada waktu isteri dalam keadaan suci yang telah digauli dan mentalak isteri dalam keadaan haidh. Kemudian, yang dimaksud dengan masa iddah dalam ayat tersebut ialah masa suci seorang isteri yang belum digauli suami. terhadap interpretasi keadaan masa iddah seperti tergambar dalam bunyi ayat tersebut menjadi konsensus (ijma'/kesepakatan) ulama fiqh maupun ulama tafsir. ${ }^{6}$

\footnotetext{
${ }^{5}$ Surah al-Thalaq [65]:1

${ }^{6}$ Amir, Syarifuddin, Hukum Perkahwinan Islam di Indonesia; Antara Fiqh Munakahat dan Undang-Undang Perkahwinan, (Cet. III, Jakarta: Kencana Prenada Media Group, 2009), h. 218.
} 
Para fuqaha sepakat menyatakan bahawa hikmah perceraian itu harus dilakukan ketika isteri dalam keadaan suci daripada haidh adalah untuk tidak memanjangkan tempoh iddah mereka iaitu tiga quru' (tiga kali suci menurut jumhur fuqaha atau tiga kali haidh menurut Imam Hanafi). ${ }^{7}$ Tempoh iddah tersebut harus dimulai perkiraannya samada daripada suci atau haidh. Sekiranya isteri ditalak ketika haidh, permulaan iddah hanya bermula setelah isteri suci daripada haidh keduanya mengikut pandangan jumhur. Manakala Imam Hanafi menghitung iddah bermula daripada haidh kali kedua. Kedua-dua perhitungan iddah ini hakikatnya memanjangkan tempoh iddah bagi kaum isteri.

Aturan yang ditetapkan Allah swt itu adalah yang paling adil untuk kaum wanita. Berlaku adil seperti ini adalah amat dituntut dalam apa agama sekalipun, lebih-lebih lagi dalam agama Islam yang mengangkat darjat dan martabat kaum wanita serta amat menghormati kedudukan mereka.

Justeru, perceraian juga boleh mendapat keredhaan Allah swt sekiranya perceraian tersebut dilakukan mengikut aturan dan adab yang telah ditetapkan olehNya. Terkait dengan adanya aturan perceraian, terdapat pula aturan hukum yang diteorikan oleh ulama fiqh (fuqaha) mengenai talak sunni dan talak bid'i. Talak sunni merupakan talak yang dijatuhkan suami terhadap isterinya dengan cara sebagaimana telah digariskan dalam Islam, artinya suami menceraikan isteri dalam waktu dan keadaan yang tepat. Sedangkan menurut Amir Syarifuddin, dengan redaksi yang berbeda, menyebutkan talak sunni sebagai talak yang pelaksanaannya telah sesuai dengan petunjuk agama dalam al-Quran atau sunnah nabi. Bentuk talak yang disepakati oleh ulama iaitu talak yang dijatuhkan oleh suami yang mana isteri tidak dalam keadaan haidh atau dalam masa suci yang pada masa tersebut belum pernah dicampuri oleh suaminya. ${ }^{8}$

Kebalikan dari itu, jika suami menceraikan isterinya tidak sesuai dengan ketentuan yang ada dalam hukum Islam dinamakan dengan term atau istilah talak bid'i. Misalnya, suami menceraikan dengan bilangan tiga sekaligus, atau menceraikan isteri dalam keadaan suci yang sebelumnya pernah sempat digauli, atau menceraikan pada isterinya lagi haidh. ${ }^{9}$ Kedudukan talak terhadap isteri yang haidh (menstruasi) seperti disebut terakhir menjadi kajian dalam pembahasan ini. Terdapat keterangan dalam beberapa literatur fiqh, bahwa seluruh ulama sepakat mengenai hukum talak yang dijatuhkan suami ketika isterinya dalam keadaan haidh (menstruasi) sebagai jenis talak bid'i yang diharamkan dan pelakunya berdosa. ${ }^{10}$ Kendati demikian, ulama berikhtilaf atau selisih pendapat mengenai kedudukan hukum yang dijatuhkan, apakah talak tersebut jatuh atau tidak. Secara umum, pendapat

\footnotetext{
${ }^{7}$ Wahbah al-Zuhaily, Fiqh al-Islam wa Adillatuhu, (Cet.II, Damshiq: Darul Fikr,1985), Jld 5, h.152.

${ }^{8}$ Amir Syarifuddin, Hukum Perkahwinan Islam Antara Fiqh Munakahat dan Undang-Undang Perkahwinan, (Cet. III, Jakarta: Kencana Prenada Media Group, 2009), h. 217.

${ }^{9}$ Sayyid Sabiq, Fiqh Sunnah, (terj: Asep Sobari, dkk), jilid 2, (Cet. II, Jakarta: Al-I ${ }^{\mathrm{ee}}$ Tishom, 2013), h. 447.

${ }^{10}$ Muhammad Jawad Mughniyyah, Fiqih Lima Mazhab; Ja'fari, Hanafi, Maliki, Syafi'i, Hanbali, (terj: Masykur AB, dkk), (Cet. XVIII, Jakarta: Lentera, 2006). H. 444-445.
} 
tersebut dibagi ke dalam dua bagian, pertama iaitu menurut menurut mayoritas ulama mazhab seperti mazhab Hanafi, Maliki, Syafi'i serta mazhab Hambali, demikian juga menurut al-Hasan al-Basri, Atha" bin Abi Rabah, ats-Tsauri, al-Auza'i serta Abu Tsaur, mereka mengatakan bahwa talak tersebut tetap berlaku dan dihitung sebagai bilangan talak, tetapi laki-laki tersebut dalam keadaan berdosa. ${ }^{11}$

Dalam firman Allah swt yang telah dipamerkan sebelum ini tidak menjelaskan kondisi hukum dan status perceraian yang dilakukan ketika isteri dalam keadaan haidh. Yang dizahirkan hanyalah adab menceraikan isteri haruslah menjamin kema'rufan dan menghindari dhirar (kemudharatan). Namun, sebuah hadis ditemui untuk menjawab persoalan ini. Justeru, penulis akan cuba merungkai beberapa masalah yang menjadi pokok persoalan: Bagaimana redaksi hadis tentang talak isteri ketika haidh?; Bagaimana status redaksi hadis dan sanad tentang talak isteri ketika haidh?; Bagaimana kondisi hukum dan status perceraian tersebut perspektif lintas mazhab?. Adapun artikel ini bertujuan untuk: Mengetahui redaksi hadis tentang talak isteri ketika haidh; Meneliti dan menganalisis status redaksi hadis dan sanad tentang talak isteri ketika haidh; Mengetahui kondisi hukum dan status perceraian tersebut perspektif lintas mazhab. Manfaat Penulisan, Secara teoritis, artikel ini diharapkan dapat menjadi rujukan bagi peneliti yang hendak meneliti hukum talak isteri dalam keadaan haidh yang dikategorikan sebagai talak bid'i. Secara praktis, artikel ini diharapkan dapat memberi pemahaman yang benar mengenai adab dan aturan perceraian yang digariskan oleh syara' agar pesanan Allah swt dan Rasulullah saw untuk berlaku adil ke atas kaum wanita dapat dihayati dan dipraktis walaupun ketika melakukan perceraian.

\section{METODE}

Jenis penelitian ini adalah penelitian kepustakaan (Library research), karena objek kajiannnya adalah hal yang berhubungan dengan litelatur-litelatur kepustakaan. ${ }^{12}$ Jika dilihat dari sifatnya, maka data dalam penelitian ini merupakan data kualitatif yang bersifat explanatory research, yang menjelaskan, memperkuat, menguji ataupun menolak suatu teori, yang dalam penelitian ini tentang teori yang terkait dengan hukum talaq isteri ketika haidh: satu analisis hadith dan fiqh.

\footnotetext{
${ }^{11}$ Shalih bin Abdulah al-Lahim, al-Ahkamal-Murattibah 'ala al-Haidhi wa alNifasi wa al-Istishadhati; Fiqih Darah Wanita, (terj: Nurul Mukhlisin), (Cet. II, Surabaya: Pustaka Elba, 2012), h. 243.

${ }^{12}$ Winarno Surahmad, Pengantar penelitian Ilmiah, (Bandung: Tarsito, 1990), h. 182
} 


\section{PEMBAHASAN}

\section{Redaksi Matan (teks) Hadis Talak Isteri Ketika Haidh}

Terdapat beberapa redaksi hadis oleh para muhaddis hadis berkaitan talak isteri ketika haidh namun kesemuanya datang dari perawi yang satu iaitu Abdullah bin Umar ra serta menunjukkan kesimpulan hukum yang sama, di antaranya:

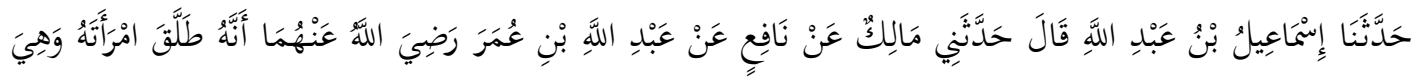

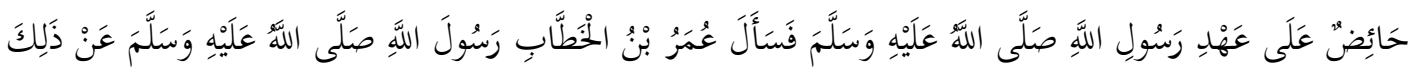

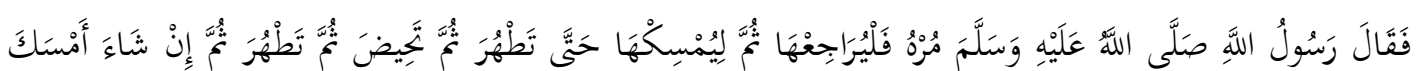

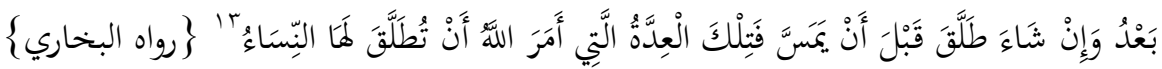

Artinya: ..."Sesungguhnya Abdullah ibn Umar telah menceraikan istrinya yang dalam keadaan Haidh pada zaman Rasulullah saw. Hal kemudian diberitahukan Umar kepada Nabi saw. Maka Nabi saw. Berkata kepada Umar, perintahkan Abdullah untuk merujuknya dan bila telah suci, maka biarkan ia sampai haidh, dan bila suci lagi, sekiranya beliau masih mengingini isterinya, maka kekalkan (tidak cerai), dan sekiranya beliau mau menceraikan maka ceraikan sebelum ia menggauli isterinya.Demikianlah iddah yang diperintahkan Allah dalam menceraikan isteri”.

$$
\begin{aligned}
& \text { عن ابنِ عمرَ؛ أنه طلق امرأتهه وهي حائضٌ. في عهدِ رسولِ اللهِ صلَّى اللهُ عليهِ وسلَّمَ. فسأل عمرُ بنُ الخطابِ رسولَ }
\end{aligned}
$$

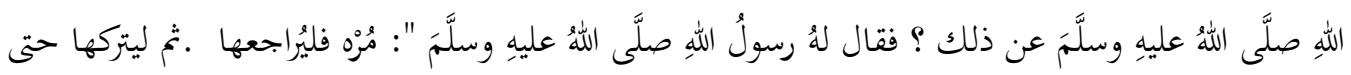

$$
\begin{aligned}
& \text { تطهرَ . ثم تحيضَ. ثم تطهرَ. ثم، إن شاء أمسك بعد، وإن شاء طلق قبل أن يمسَّ. فتلك العدةُ التي أمر اللهُ عزَّ } \\
& \text { وجلَّ أن يطلق لها النساءُ ". عاء } \\
& \{\text { \{ رواه } \\
& \text { وفي روايةٍ: عن عبدِاللهِ ؛ أنه طلق امرأةً لهُ وهي حائضُ. تطليقةً واحدةً. فأمَه رسولُ اللهِ صلَّى اللهُ عليهِ وسلَّمَ أن }
\end{aligned}
$$

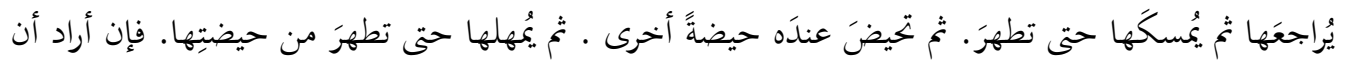

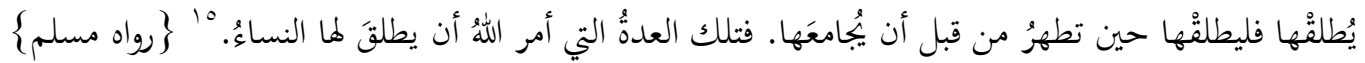

\footnotetext{
${ }^{13}$ Ibn Hajar al-Asqalani, Fathul Bari Syarh Shahih al-Bukhari: No Hadis $\leqslant \wedge \bullet \cdot:$ Kitab al-Talak, Bab: Iza Tulliqat alHaidhu Tu'taddu bizalika al-Talaq

${ }^{14}$ Al-Nawawiy, Shahih Muslim bi Syarh al-Nawawiy (Beirut: Dar al-Fikr, 1978) Shahih Muslim, No Hadis 1471

${ }^{15}$ Al-Nawawiy, Shahih Muslim bi Syarh al-Nawawiy (Beirut: Dar al-Fikr, 1978) Shahih Muslim, No Hadis 1471
} 


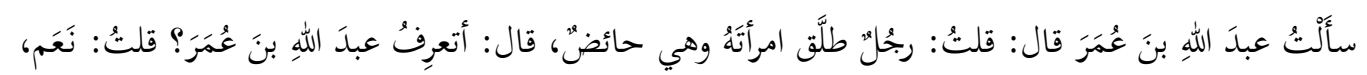

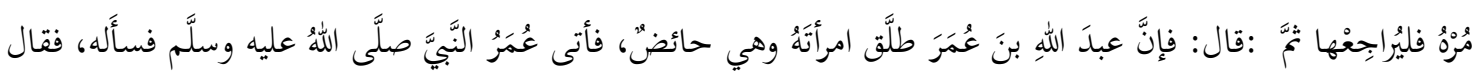

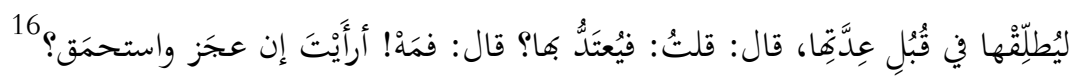
$\{2$ واؤي

Artinya: "Aku bertanya Abdullah bin Umar: Seorang telah menceraikan isterinya yang sedang haidh, berkata, Adakah kamu kenal Abdullah bin Umar? Lalu dijawab: Ya. "Aku mendengar bahwa Ibnu 'Umar pernah mentalak isterinya dalam keadaan haidh. Lalu 'Umar mendatangi Nabi shallAllahu 'alaihi wa sallam kemudian mengadukan perihal anaknya. Nabi saw bersabda, "Perintah ia untuk rujuk pada isterinya. Jika isterinya telah suci dan ia mau, ia boleh mentalaknya." Yunus berkata pada Ibnu 'Umar, "Apakah engkau menganggap jatuh talak?" Ibnu 'Umar menjawab, "Apa yang menghalanginya? Talak tersebut tidak terhalang walau kerana kelemahan atau kebodohannya.

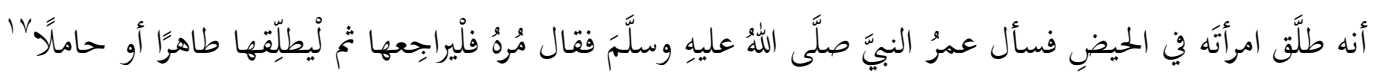

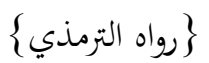

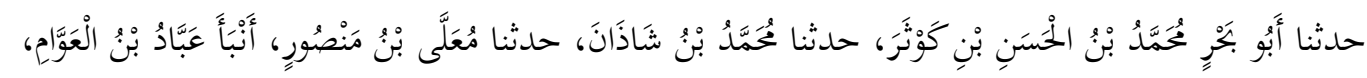

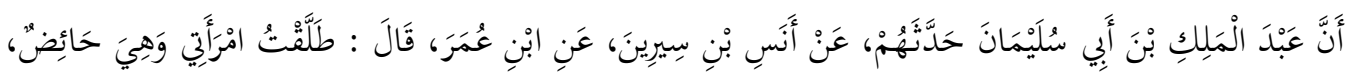

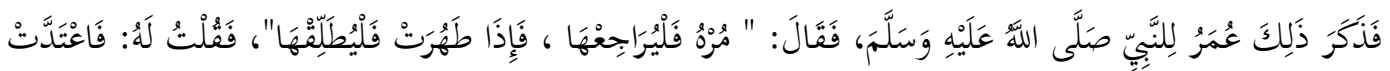

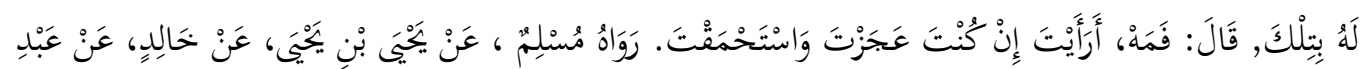
'الْمِلِكَ

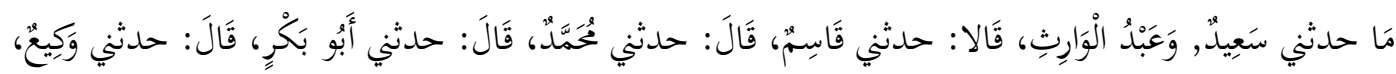

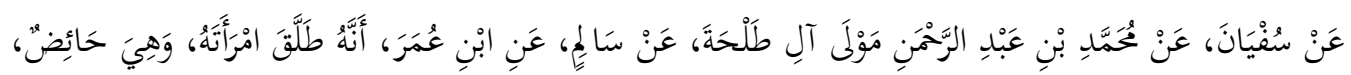

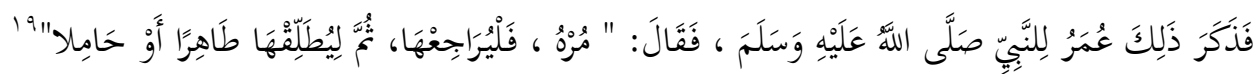

\footnotetext{
${ }^{16}$ Sunan Abi Daud, No Hadis 2184

${ }^{17}$ Abu Isa Muhammad bin Isa as-Sulami at-Turmuzi, Sunan al-Tirmizi, Sunan al-Tirmizi, No Hadis 11 vo

${ }^{18}$ Al-Nawawiy, Shahih Muslim bi Syarh al-Nawawiy (Beirut: Dar al-Fikr, 1978) No Hadis 3197.

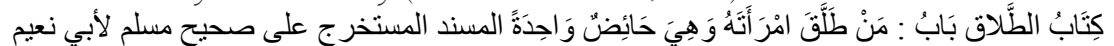

${ }^{19}$ Salem Muhammad Abu Amr Yusof al-Qurtubi, Al-Istizkar, Tahqiq: Muhammad Ali Muawwadh, Beirut: Darul Kutub al-Ilmiyah, 2000), No Hadis 677
}

$$
\text { كتاب الطلاق باب ما جاء في الأقر اءو عدة الطلاق وطلاق الحائض }
$$




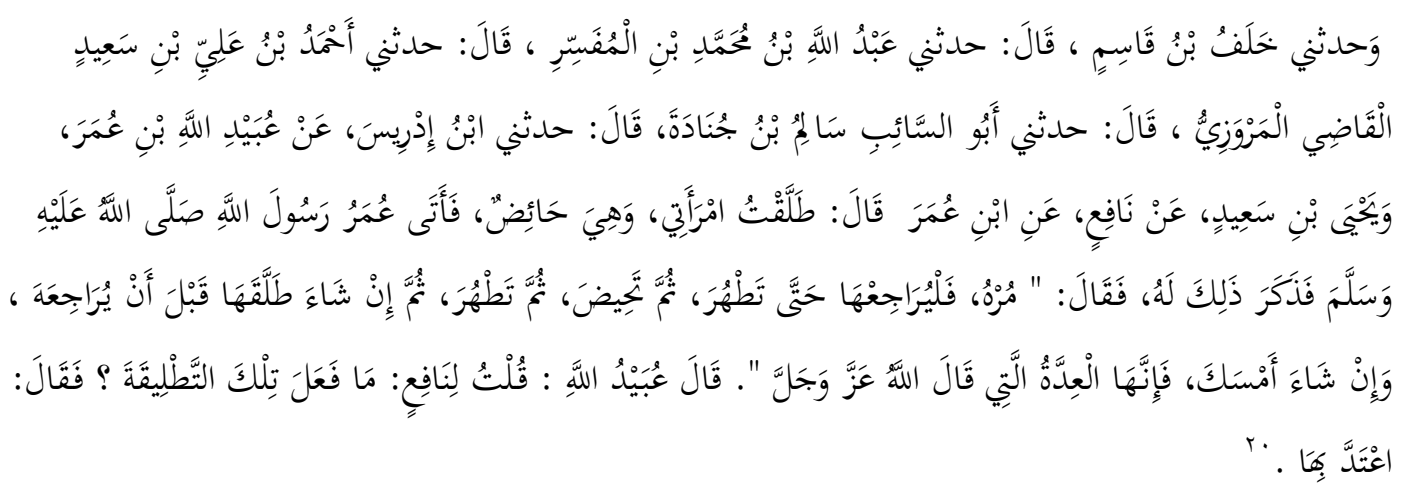

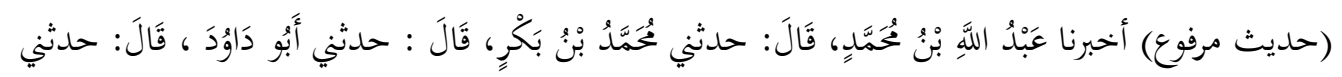

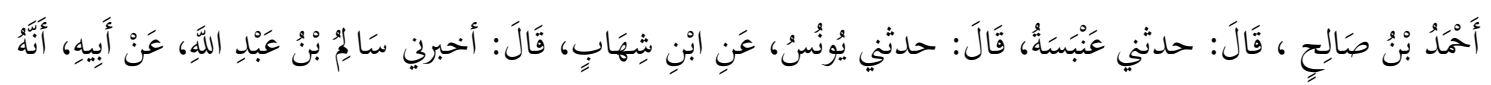

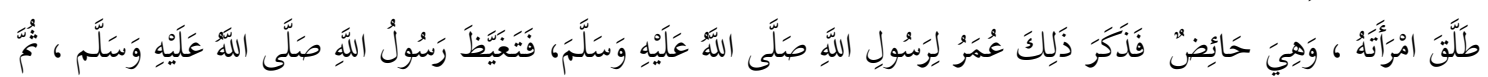

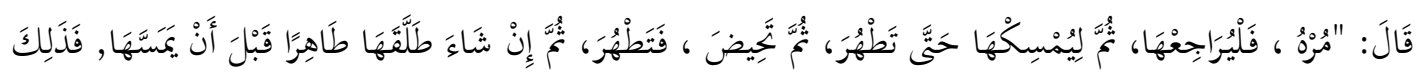

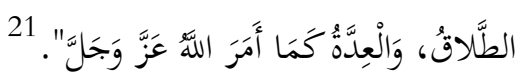

\section{Syarah Hadis}

Dalam hadis ini, Ibn Umar ra telah menceraikan isterinya yang bernama Aminah binti Ghifar atau Aminah binti Ammar dan beliau dalam keadaan haidh. Peristiwa ini berlaku pada zaman nabi saw. Ibn Umar ra coba mendapatkan kepastian daripada bapanya Umar ra, lalu Umar segera mendapatkan Rasulullah saw apakah diharuskan talak ketika isteri haidh atau sebaliknya? dan apakah jatuh talak atau sebaliknya? Maka Rasulullah saw memerintahkan Umar ra agar menyuruh anaknya untuk merujuk isteri yang ditalak. Seterusnya nabi saw memerintahkan agar menunggu sehinggaa isterinya dalam keadaan suci setelah haidh yang diceraikan sehingga datang haidh yang kedua dan menunggu lagi sehingga suci daripada haidh yang kedua. Ketika dalam keadaan suci inilah Rasulullah menasihati Ibn Umar samada ingin meneruskan perceraian atau meneruskan hubungan suami isteri, nabi juga mensyaratkan sekiranya ingin meneruskan perceraian maka beliau tidak boleh menggauli isterinya ${ }^{22}$. Isteri hanya layak diceraikan hanya ketika dalam keadaan suci (suci setelah haidh kedua) sesuai dengan perintah Allah swt melalui ayat pertama surah

\footnotetext{
${ }^{20}$ Salem Muhammad Abu Amr Yusof al-Qurtubi, Al-Istizkar, Tahqiq: Muhammad Ali Muawwadh, Beirut: Darul Kutub al-Ilmiyah, 2000), No Hadis 681

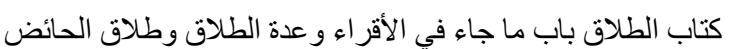

${ }^{21}$ Salem Muhammad Abu Amr Yusof al-Qurtubi, Al-Istizkar, Tahqiq: Muhammad Ali Muawwadh, Beirut: Darul Kutub al-Ilmiyah, 2000), No Hadis 679

${ }^{22}$ Al-Nawawiy, Shahih Muslim bi Syarh al-Nawawiy (Beirut: Dar al-Fikr, 1978) No Hadis 3197.
} 
al-Talaq sebagaimana yang telah penulis jelaskan di awal perbahasan mengenai konsep perceraian dalam Islam.

Dalam riwayat yang lain dimana Ibnu Umar menjawab pertanyaan Yunus ra: "Apakah engkau menganggap jatuh talak?” lalu Ibnu 'Umar menjawab: “Apa yang menghalanginya? Talak tersebut tidak terhalang walau kerana kelemahan atau kebodohannya ${ }^{23}$. Justeru dalam hal ini menunjukkan bahawa talak dalam keadaan haidh adalah dianggap talak yang sah.

Kesimpulan hadis ini diringkaskan dalam tiga perkara:

a. Apabila berlaku talak ketika isteri sedang haidh maka disunnahkan suami merujuk isteri terlebih dahulu sehingga suci daripada haidh kedua, seterusnya memutuskan samada untuk meneruskan perceraian atau mengekalkan perkahwinan

b. Talaq ketika haidh dikira sebagai satu talaq yang sah.

c. Talaq ketika haidh adalah talaq yang menyalahi aturan Allah swt dan dianggap sebagai talaq bid'i.

\section{Sabab Wurud Hadis}

Sabab wurud hadis dalam hadis yang diriwayatkan oleh Ibnu Umar ialah seperti yang telah dijelaskan pada syarah hadis tersebut di mana kes ini berlaku ke atas isteri Ibn Umar ra yang telah diceraikan oleh Ibn Umar ra. Pada hakikatnya Ibn Umar ra tidak mengetahui tentang hukum perbuatannya samada diharuskan talak ketika isteri sedang haidh atau sebaliknya dan apakah jatuh talaq tersebut atau sebaliknya. Justeru beliau mendapatkan kepastian daripada bapanya iaitu Umar ra namun Umar juga tidak berapa pasti tentang kondisi talak tersebut lalu beliau meminta penjelasan langsung daripada Rasulullah saw.

Daripada kes ini jelas menunjukkan bahawa perbuatan Ibn Umar telah menyalahi aturan talak yang telah Allah swt jelaskan dalam surah al-Thalaq:1 dan surah al-Baqarah: 231, dimana perempuan itu harus ditalaqkan mengikut hitungan iddah mereka iaitu ketika mereka dalam keadaan suci. Talaq ketika suci adalah sunnah yang diaturkan Allah swt demi menjaga maslahah kaum perempuan ianya dikategorikan talaq sunni oleh majoriti fuqaha, manakala talak ketika haidh adalah talak yang menyalahi sunnah lalu dikategorikan sebagai talaq bid'i.

\section{Analisis Jalur Periwayatan dan Sanad Hadis}

Hadis mengenai talak isteri ketika haidh diklasifikasikan sebagai hadis marfu' yang penghujung sanadnya adalah langsung daripada Rasulullah saw dengan status matan hadis shahih serta diriwayatkan melalui 100 jalur periwayatan. Satu jumlah jalur periwayatan

${ }^{23}$ Ibn Hajar al-Asqalani, Fathul Bari Syarh Shahih al-Bukhari: Bab:"Iza Tulliqat al-Haidh tu'taddu bizalika alTalaq.”jld 9 
amat besar yang menunjukkan kekukuhan sesebuah hadis. Berikut adalah ringkasan analisis jumlah jalur periwayatan hadis Abdullah Ibn 'Umar r.a mengenai hukum talak isteri ketika dalam keadaan haidh:

\begin{tabular}{|c|c|c|c|}
\hline Bil. & $\begin{array}{l}\text { JALUR } \\
\text { PERIWAYATAN }\end{array}$ & $\begin{array}{l}\text { SUMBER } \\
\text { (KITAB) }\end{array}$ & $\begin{array}{l}\text { JML. } \\
\text { JALUR }\end{array}$ \\
\hline 1 & $\begin{array}{l}\text { Muhammad bin Ismail al- } \\
\text { (Imam al-Bukhari) }\end{array}$ & Shahih al-Bukhari & 7 \\
\hline 2 & $\begin{array}{l}\text { Muslim bin al-Hajjaj } \\
\text { (Imam Muslim) }\end{array}$ & Shahih Muslim & 14 \\
\hline 3 & $\begin{array}{l}\text { Muhammad bin Isa } \\
\text { (Imam al-Tirmizi) }\end{array}$ & Jami' al-Tirmizi & 2 \\
\hline 4 & $\begin{array}{l}\text { Abu Daud al-Sajistani } \\
\text { (Imam Abi Daud) }\end{array}$ & Sunan Abi Daud & 5 \\
\hline 5 & Imam al-Nasa-i & $\begin{array}{l}\text { Sunan al-Nasa-i } \\
\text { al-Sughra }\end{array}$ & 14 \\
\hline 6 & Imam Ibn Majah & Sunan Ibn Majah & 3 \\
\hline 7 & $\begin{array}{l}\text { Abdullah bin Abd Rahim } \\
\text { (Imam al-Darimi) }\end{array}$ & Sunan al-Darimi & 2 \\
\hline 8 & Imam Malik bin Anas & $\begin{array}{l}\text { Muwatta' Malik } \\
\text { Riwayah Yahya } \\
\text { al-Laythi }\end{array}$ & 1 \\
\hline 9 & Imam Ahmad bin Hanbal & $\begin{array}{l}\text { Musnad Ahmad bin } \\
\text { Hanbal }\end{array}$ & 23 \\
\hline 10 & $\begin{array}{l}\text { Abu Hatim } \\
\text { (Imam Ibn Hibban) }\end{array}$ & Shahih Ibn Hibban & 2 \\
\hline 11 & $\begin{array}{l}\text { Imam Abi 'Awwamah al- } \\
\text { Isfirayni }\end{array}$ & $\begin{array}{l}\text { Mustakhraj Abi } \\
\text { 'Awwamah }\end{array}$ & 18 \\
\hline 12 & $\begin{array}{l}\text { Imam Abu Na'eem al- } \\
\text { Asbahani }\end{array}$ & $\begin{array}{l}\text { Al-Musnad al- } \\
\text { Mustakhraj 'ala Shahih } \\
\text { Muslim li Abi Na'eem }\end{array}$ & 9 \\
\hline \multicolumn{3}{|c|}{ JUMLAH KESELURUHAN JALUR } & 100 \\
\hline
\end{tabular}

Sumber: http://library.islamweb.net/hadith/hadith

Manakala sanad hadis ini adalah sahih, para perawinya adalah perawi yang thiqah semua dan tergolong perawinya Imam al-Bukhari, Imam Muslim, Imam Abi Daud, Imam al-Nasa-i, Imam Ibn Majah, Imam Malik, Imam Ahmad Hanbal dan yang lainnya.

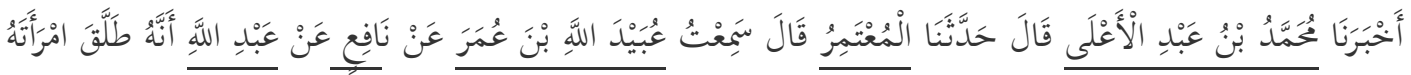

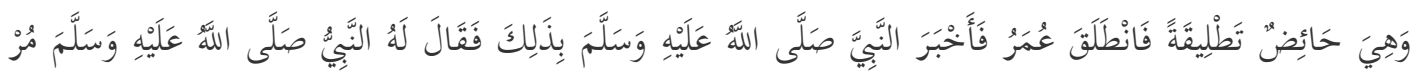

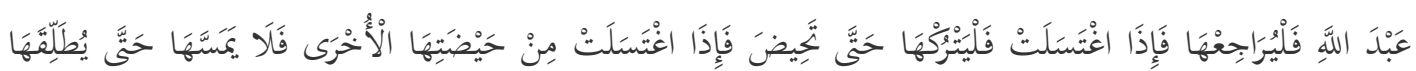

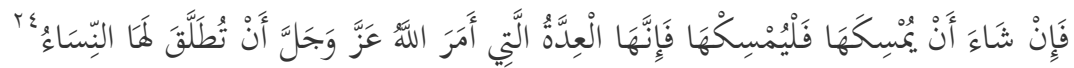

\footnotetext{
${ }^{24}$ Imam Al-Nasa'i, Sunan al-Nasa'i, (Beirut: Dar al- Fikr, t.th), h.252.
} 
Artinya: "Sesungguhnya Abdullah ibn Umar menceraikan isterinya yang dalam keadaan haidh. Hal kemudian diberitahukan Umar kepada Nabi saw. Maka Nabi saw. Berkata kepada Umar, perintahkan Abdullah untuk merujuknya dan bila telah suci, maka biarkan ia sampai haidh, dan bila suci lagi, maka janganlah "disentuh" sampai ia diceraikan, atau tetap dipertahank.an(tidah diceraikan). Demikianlah 'iddah yang diperintahkan Allah dalam menceraikan isteri”.

Hadis di atas ditakhrij oleh al-Nasai melaui sanad Muhammad ibn Abd al-A'la ke Mu'tamir ke Ubaidillah ibn Umar ke Nafi' ke Abdullah ibn Umar lalu ke Nabi saw. Dengan demikian, Dalam penelitian sanad, periwayat yang akan diteliti secara berurut adalah sebagai berikut: periwayat pertama adalah 'Abd Allah (Ibn 'Umar); periwayat kedua adalah Nafi'; Periwayat ketiga adalah 'Ubaid Allah ibn 'Umar; periwayat keempat adalah Mu'tamir; periwayat kelima adalah Muhammad ibn 'Abd al-A'la; dan periwayat keenam adalah al-Nasa'iy dan diringkaskan sebagaimana berikut:

\begin{tabular}{|l|l|l|l|}
\hline \multicolumn{2}{|l|}{ PERAWI } & $\begin{array}{l}\text { TAHUN } \\
\text { KEWAFATAN }\end{array}$ & $\begin{array}{l}\text { STATUS } \\
\text { PERAWI }\end{array}$ \\
\hline 1 & 'Abd Allah (Ibn 'Umar) & $73 \mathrm{H}$ & Thiqah \\
\hline 2 & Nafi' & $116 \mathrm{H}$ & Thiqah \\
\hline 3 & Ubaidillah ibn 'Umar & $145 \mathrm{H}$ & Thiqah \\
\hline 4 & Mu'tamir & $187 \mathrm{H}$ & Thiqah \\
\hline 5 & Muhammad ibn 'Abd al-A'la & $245 \mathrm{H}$ & Thiqah \\
\hline 6 & Imam al-Nasa'i & $303 \mathrm{H}$ & Thiqah \\
\hline
\end{tabular}

Sumber: http://library.islamweb.net/hadith/hadith

Abd Allah

Nama lengkapnya adalah 'Abdullah ibn 'Umar ibn al-Khattab ibn Nufail alQurasy al-'Adawiy ${ }^{25}$. Ia masuk Islam bersama ayahnya, dan saat itu ia belum balig, dan ada yang mengatakan ia lebih dahulu memeluk Islam dari ayahnya. Selain itu ia adalah orang yang terkenal akan kesalehannya. Ia juga termasuk salah seorang dari kelompok. "alabādilah” yang alim ${ }^{26}$.Ibn 'Umar meriwayatkan hadis-hadis langsung dari Nabi saw.; Umar ibn Khattab (ayahnya); Zaid (pamannya); Hafsah (saudara perempuannya) Abu Bakar alSiddiq, 'Usman ibn 'Affan, Ali ibn Abli Thalib; Zaid ibn Tsabit dan lain-lain. Adapun

${ }^{25}$ Syihab al-Din ibn al-Fadhl Ahmad ibn Hajar al-Asqallaniy, Tahzib al-Tahzib, juz V (Beirut: Dar al-Kutub al'Ilmiyyah, 1993), h. 293

${ }^{26}$ Izz al-Din ibn al-Atsir Abu Hasan Ali ibn Muhammad al-Jaziriy, Usud al-Ghabat fi Ma'rifat al-Shahabah, Juz III (Beirut: Dar al-Fikr, t.th.), h. 237. Lihat Juga Mahmud al-Tahhan, Taysir Mushttalah al-Hadis. Diterjemahkan oleh Zainul Muttaqin dengan judul Ulumul Hadis (Yogyakarta: Titian Ilahi Press, 1997), h. 233 
hadis-hadisnya, diriwayatkan pula oleb Nafi, Aslam (pembantu 'Umar), Zaid dan Khalid (keduanya anak Aslam), 'Urwah ibn Zubair dan lain-lain. ${ }^{27}$

\section{Nafi'}

Nama aslinya adalah Abar Syahar. Ia adalah maula/pembantu 'Abdullah ibn Umar alKhattab yang berasal dari Naisaburi, ada juga yang mengatakan ia berasal dari Maghribi ${ }^{28}$. Nafi meriwayatkan hadis-hadis Nabi saw., bersumber dari 'Abd Allah ibn 'Umar; dalam hal ini Basyar ibn 'Umar al-Zahraniy meriwayatkan bahwa Malik ibn Anas pernah berkata bahwa "apabila aku mendapatkan hadis yang datangnya dari Nafi' yang bersumber dari 'Abd Allah ibn Umar, maka aku tidak peduli lagi dengan yang lainnya ${ }^{29}$." Menurut Imam Ibn Hirasy dan al-Ijliy bahwa Nafi' adalah seorang yang tsiqah. Sedangkan menurut Imam al-Bukhari Nafi' adalah seorang yang paling baik sanadnya ${ }^{30}$. Hadis-hadis Nafi diriwayatkan juga oleh 'Ubaid Allah ibn 'Umar, 'Ata' al-Khurasaniy, 'Ata' ibn Khalid al-Makhzumiy, Uqail ibn Khalid al-Aily. 'Ali ibn al-Hakim al-Bunaniy. dan lain-lain. ${ }^{31}$

Ubaidillah ibn 'Umar

Nama lengkapnya adalah 'Ubaidillah ibn 'Umar ibn Hafsah ibn 'Asim ibn 'Umar ibn al-Khattab ${ }^{32}$. Hadis-hadis yang diriwayatkannya bersumber dari Nafi', 'Umar ibn Nafi (anak.Nafi') al-Qasim ibn Muhammad ibn Abi Bakar, dan lain-lain ${ }^{33}$. Adapun hadis-hadisnya diriwayatkan pula oleh Mu'tamir, Yahya ibn Abi Zaidah al-Qatthan, Abu Khalid al-Ahmar, 'Abd al-Wahhab al-Tsaqafi, Uqbah ibn Khalid al-Sukuny, Isa ibn Yunus, dan lain-lain ${ }^{34}$. Menurut Imam Ahmad ibn Hanbal bahwa 'Ubaidillah adalah seorang yang tsabit, kuat hafalannya, serta banyak meriwayatkan hadis-hadis Nabi saw ${ }^{35}$.

Mu'tamir

\footnotetext{
${ }^{27}$ Syihab al-Din ibn al-Fadhl Ahmad ibn Hajar al-Asqallaniy, Tahzib al-Tahzib, juz V (Beirut: Dar al-Kutub al'Ilmiyyah, 1993), h. 292

${ }_{28}$ Al-Hafiz Jamal al-Din al-Hajja Yusuf al-Mizziy, Tahzib al-Kamal fi Asma al-Rijal, Juz XIX (Beirut: Dar al-Fikr, 1994), h. 32

${ }^{29}$ Al-Hafiz Jamal al-Din al-Hajja Yusuf al-Mizziy, Tahzib al-Kamal fi Asma al-Rijal, Juz XIX (Beirut: Dar al-Fikr, 1994), h. 35

${ }^{30}$ Al-Hafiz Jamal al-Din al-Hajja Yusuf al-Mizziy, Tahzib al-Kamal fi Asma al-Rijal, Juz XIX (Beirut: Dar al-Fikr, 1994), h. 36

${ }^{31}$ Al-Hafiz Jamal al-Din al-Hajja Yusuf al-Mizziy, Tahzib al-Kamal fi Asma al-Rijal, Juz XIX (Beirut: Dar al-Fikr, 1994), h. 34

${ }^{32}$ Syihab al-Din ibn al-Fadhl Ahmad ibn Hajar al-Asqallaniy, Tahzib al-Tahzib, juz V (Beirut: Dar al-Kutub al'Ilmiyyah, 1993), Juz VII, h. 34

${ }^{33}$ Syihab al-Din ibn al-Fadhl Ahmad ibn Hajar al-Asqallaniy, Tahzib al-Tahzib, juz V (Beirut: Dar al-Kutub al'Ilmiyyah, 1993), Juz VII, h. 35

${ }^{34}$ Syihab al-Din ibn al-Fadhl Ahmad ibn Hajar al-Asqallaniy, Tahzib al-Tahzib, juz V (Beirut: Dar al-Kutub al'Ilmiyyah, 1993), Juz VII, h. 35

35 Al-Hafiz Jamal al-Din al-Hajja Yusuf al-Mizziy, Tahzib al-Kamal fi Asma al-Rijal, (Beirut: Dar al-Fikr, 1994),Juz XII, h. 248-249
} 
Nama lengkapnya adalah Mu'tamir ibn Sulaiman ibn Tarkhan al-Taimiy ${ }^{36}$. Hadis-hadis yang diriwayatkannya bersumber dari Ubaid Allah ibn Umar, Kahmas ibn al-Hasan, Muhammad ibn 'Umar ibn 'Alqamah, Ishaq ibn Suwaid al-Adawiy, dan lain-lain ${ }^{37}$. Sedangkan hadis-hadisnya diriwayatkan juga oleh Muhammad Ibn 'Abd alA'la, al-Tsauri, Ibnu Mubarak, 'Abd al-Rahman ibn Mahdiy, 'Abd al-Razzaq, 'Abd Allah ibn Ja'far al-Raqiy, dan lain-lain ${ }^{38}$. Menurut Ibnu Sa'ad bahwa Mu'tamir adalah seorang yang Tsiqah, demikian juga dengan pendapat Ibnu Ma'in. ${ }^{39}$

Muhammad ibn Abd al-A'la

Nama lengkapnya adalah Muhammad ibn' Abd al-A'la al-San'aniy alQaisiy. ${ }^{40}$ Hadis-hadis yang diriwayatkannya berasal dari Mu'tamir, Yazid ibn Zarr, Abu Bakar ibn 'Iyas; Sufyan ibn 'Uyainah, Isma'il ibn Aliyah, dan lain-lain'. Adapun hadis-hadisnya diriwayatkan pula oleh oleh al-Nasa'iy, al-Turmuziy, Ibnu Majah, dan lain-lain. Selain itu Imam Muslim meriwayatkan, hadis darinya sebanyak 25 buah hadis. Sedangkan Imam al-Nasa'i berkata bahwa Muhammad ibn 'Abd al-A'la adalah seorang yang baik. ${ }^{42}$

\section{Imam al-Nasa'i}

Nama lengkapnya adalah Abu 'Abd al-Rahman Ahmad ibn Syu'aib ibn Bahr. Nama Nasa'i yang berada dibelakang namanya tersebut adalah merupakan penisbatan pada kota kelahirannya di Khurasan. Menurut sebagian ulama bahwa dari segi hafalan, Imam alNasa'iy lebih unggul dari Imam Muslim. Selain itu, ia adalah seorang yang dikenal dengan kewaraan dan ketaqwaannya. ${ }^{43}$

Berdasarkan penjelasan tersebut di atas, maka dapat dipahami bahwa hubungan antara 'Abd Allah ibn Umar dengan Nafi' bukan saja hubungan antara guru dan murid, tapi lebih dari itu bahwa Nafi' adalah maula 'Abd Allah ibn 'Umar. Dengan demikian, persambungan sanad antara keduanya sangat erat dan tidak dapat diragukan. Adapun

\footnotetext{
36 Syihab al-Din ibn al-Fadhl Ahmad ibn Hajar al-Asqallaniy, Tahzib al-Tahzib, juz V (Beirut: Dar al-Kutub al'Ilmiyyah, 1993), Juz X h. 205

${ }^{37}$ Syihab al-Din ibn al-Fadhl Ahmad ibn Hajar al-Asqallaniy, Tahzib al-Tahzib, juz V (Beirut: Dar al-Kutub al'Ilmiyyah, 1993), Juz X h. 205

${ }^{38}$ Syihab al-Din ibn al-Fadhl Ahmad ibn Hajar al-Asqallaniy, Tahzib al-Tahzib, juz V (Beirut: Dar al-Kutub al'Ilmiyyah, 1993), Juz X h. 205

${ }^{39}$ Syihab al-Din ibn al-Fadhl Ahmad ibn Hajar al-Asqallaniy, Tahzib al-Tahzib, juz V (Beirut: Dar al-Kutub al'Ilmiyyah, 1993), Juz X h. 206

40 Syihab al-Din ibn al-Fadhl Ahmad ibn Hajar al-Asqallaniy, Tahzib al-Tahzib, juz V (Beirut: Dar al-Kutub al'Ilmiyyah, 1993), Juz IX, h. 257

${ }^{41}$ Syihab al-Din ibn al-Fadhl Ahmad ibn Hajar al-Asqallaniy, Tahzib al-Tahzib, juz V (Beirut: Dar al-Kutub al'Ilmiyyah, 1993), Juz IX, h. 257

${ }^{42}$ Syihab al-Din ibn al-Fadhl Ahmad ibn Hajar al-Asqallaniy, Tahzib al-Tahzib, juz V (Beirut: Dar al-Kutub al'Ilmiyyah, 1993), Juz IX, h. 257

${ }^{43}$ Fathurrahman, Mustalahul Hadis (Bandung: al-Ma'arif, 1995), h. 334
} 
hubungan dengan 'Ubaid Allah ibn Umar adalah hubungan guru dan murid. Sebab selain keduanya dimungkinkan untuk bertemu kerana selisih umur keduanya memungkinkan, juga kerana periwayat (Nafi') dan yang menerima riwayat ('Ubaid Allah), diantarai oleh huruf "ع" yang memungkinkan terjadi pertemuan. Selain itu tidak ada indikasi penyembunyian informasi (tadlis) yang dilakukan oleh periwayat tersebut ${ }^{44}$. Sedangkan 'Ubaid Allah dengan Mu'tamir, tampaknya terdapat hubungan antara guru dan murid juga. Sebab lafaz "سمعت" yang digunakan oleh Mu'tamir, adalah merupakan petunjuk bahwa ia (Mu'tamir) telah mendengar sendiri riwayat hadis tersebut dari 'Ubaidillah" ${ }^{45}$.

Demikian juga halnya antara Mu'tamir dengan Muhammad ibn 'Abd al-A'la. Antara keduanya juga terjadi hubungan guru dan murid yang pernah bertemu satu sama lainnya. Sebab metode periwayatan hadis yang digunakan adalah "حدثن" yang mengindikasikan bahwa ia (Muhammad ibn 'Abd al-A'la) mendengar sendiri dari gurunya (Mu'tamir) ${ }^{46}$.

Mengenai Muhammad ibn 'Abd al-A'la dengan lmam al-Nasa'iy, maka hubungan keduanya adalah antara guru dan murid. Sebab metode "أخبرنا" yang digunakan oleh Imam al-Nasa'iy menunjukkan bahwa gurunya (Muhammad ibn 'Abd al-A'la) menyampaikan dengan menghadapkan riwayatnya kepada periwayat/mukharrij al-Hadis, iaitu al-Nasa' ${ }^{47}{ }^{47}$

Dengan adanya persambungan sanad dan dengan adanya ketsiqahan (adil dan dabith)nya para periwayat, serta tidak adanya penyembunyian informasi maka hadis yang diriwayatkan oleh al-Nasa'iy dari 'Abd Allah ibn Umar tersebut dapat dikategorikan sebagai hadis yang shahih.

Dalam penelitian suatu hadis, terkadang ditemukan sanadnya sahih tapi tidak demikian dengan matannya. Oleh kerana itu, walaupun dalam penelitian hadis riwayat alNasa'i ini telah disebutkan sebagai hadis sahih, namun masih diperlukan untuk. mengadakan penelitian terhadap matannya.

Sebagian ulama ahli hadis telah menentukan sahihnya suatu matan hadis dengan beberapa persyaratan ${ }^{48}$ :

1. Hadis itu tidak bertentangan dengan akal.

2. Hadis itu tidak bertentangan dengan hukum, al-Quran yang telah muhkam

3. Hadis itu tidak bertentangan dengan hadis yang mutawatir.

\footnotetext{
${ }^{44}$ M. Syuhudi Ismail, Kaedah Kesahihan Sanad Hadis (Jakarta: Bulan Bintang, 1995), h. 70

${ }^{45}$ M. Syuhudi Ismail, Kaedah Kesahihan Sanad Hadis (Jakarta: Bulan Bintang, 1995), h. 60

${ }^{46}$ Nur al-Din Itr, Manhaj al-Naqd fi Ulum al-Hadis. Diterjemahkan oleh H. Endang Soetari dan Mujiyo dengan judul Ulum Al-Hadis I (Bandung: Remaja Rosdakarya, 1995), h. 209

${ }^{47}$ M. Syuhudi Ismail, Kaedah Kesahihan Sanad Hadis (Jakarta: Bulan Bintang, 1995), h. 60

${ }^{48}$ M. Syuhudi Ismail, Hadis Nabi Menurut Pembela, Pengingkar dan Pemalsunya (Jakarta: Gema Insani Press, 1995), h. 79
} 
4. Hadis itu tidak bertentangan dengan amalan yang telah menjadi kesepakatan ulama-ulama salaf yang saleh.

5. Hadis itu tidak bertentangan dengan dalil yang qath’i.

6. Hadis itu tidak bertentangan dengan hadis ahad yang tingkat kualitas kesahihannya lebih kuat.

Dengan demikian, dapat difahami bahawa, dari susunan redaksi hadis tersebut tidak bertentangan dengan salah satu dari enam ketentuan di atas. Dari segi akal dapat difahami bahawa apabila seseorang mentalak isterinya dalam keadaan haidh, maka akan mendatangkan mudarat (bahaya) bagi isteri yang diceraikan itu, sebab dengan demikian masa 'iddahnya akan lebih lama. ${ }^{49}$

Hadis tersebut juga tidak bertentangan dengan QS. 65.1 yang berbunyi:

dan juga tidak bertentangan dengan hadis-hadis lainnya. Selain itu seluruh ulama dari semua mazhab telah sepakat bahwa menceraikan isteri dalam keadaan haidh haram hukumnya ${ }^{50}$. Dengan demikian, tidak ada masalah dalam matan hadis ini yang dapat mengurangi kualitasnya, sehingga dapat dikatakan bahawa matan hadis ini juga berkualitas sahih sebagaimana sanadnya. Oleh karena itu tidak dapat difahami lain kecuali bahwa hadis tersebut adalah berkualitas sahih.

\section{Hukum Talak Isteri Ketika Haidh Perspektif Mazhab Fiqh}

Hukum Suami Menceraikan Isteri Ketika Haidh:

Para fuqaha sepakat bahwa menceraikan isteri yang sedang haidh adalah talak bid'i dan talak bid'i hukumnya haram. Artinya, suami yang menceraikan isterinya pada saat haidh, dia berdosa, kerana melanggar aturan Allah dan Rasul-Nya. Sayyid Sabiq menyatakan:

$$
\text { "وأجمع العلماء على أن الطلاق البدعي حرام، وأن فاعله آثت. ، } 51
$$

Artinya: "Ulama sepakat bahwa talak bid'ah hukumnya haram, dan pelakunya berdosa." Hal yang sama juga dinyatakan dalam Mausu'ah Fiqhiyah Muyasarah:

$$
\text { “وأمّا طلاقها في حال الحيض فهو محرّم بالكتاب والسنّة والإجماع، وليس في تحريمه }
$$

\footnotetext{
${ }^{49}$ Syekh Muhammad ibn Shalih al-Usaimin, Fi al-Dima' al-Tabi'iyah li al-Nisa'. Diterjemahkan oleh Muhammad Yusuf Harun dengan Judul Darah Kebiasaan Perempuan (Jakarta: Akafa Press, 1997), h. 34

${ }^{50}$ Muhammad Jawad al-Mughniyah, al-Fiqh 'ala Mazahib al-Khamsah. Diterjemahkan oleh Afif Muhammad dengan judul Fiqh Lima Mazhab (Jakarta: Bulan Bintang, 1992), h. 168

${ }^{51}$ Sayyid Sabiq, Fiqh Sunnah, (terj: Asep Sobari, dkk), jilid 2, (Cet. II, Jakarta: Al-I'tishom, 2013) jld 2. H. 265

${ }^{52}$ Husain Bin Audah Awaysasyah, Al-Mausuah al-Fiqhiyyah al-Muyassarah Fiqh al-Kitab wa al Sunnah alMuthahharah, (Beirut: Darul Hazm, 1973), jld 5, hlmn 379
} 
Artinya: "Mentalak isteri ketika haidh hukumnya haram, berdasarkan dalil al-Quran, sunah dan sepakat ulama. Tidak ada perselisihan tentang haramnya cerai ketika haidh.

Status Hukum Perceraian samada Sah atau Tidak Sah:

Para fuqaha berbeda pendapat apakah statusnya sah ataukah tidak. Pendapat pertama menyatakan, talak bid'ah hukumnya sah. Ini adalah pendapat majoriti para ulama mazhab Maliki, Hanafi, Syafi'i dan Hanbali ${ }^{53}$. Pendapat ini turut dipilih oleh Imam al-Bukhari, Imam al-Baihaqi, Imam al-Nawawi dan yang lainnya.

Pendapat kedua menyatakan, talak bid'ah statusnya tidak sah. Ini pendapat yang dipilih Said bin Musayib, Abdullah bin Ma'mar, Thawus, Ibnu Ulaiyah, Ibn Hazm, Syaikhul Islam Ibn Taymiyyah, dan Ibnu Qayyim. ${ }^{54}$

Majoriti ulama berpendapat, talak bid'ah statusnya sah, dan dianggap sebagai talak satu. ${ }^{55}$ Namun suami diperintahkan untuk merujuk isterinya dan menahannya sampai suci dari haidh, kemudian haidh lagi yang kedua, sampai suci. Selanjutnya terserah kepada suami, apakah dia mahu menceraikannya atau mengekalkannya. Inilah pendapat majoriti ulama.

Sebagaimana keterangan Wahbah Zuhaili, bahwa talak yang terjadi terhadap isteri yang sedang haidh sebagai talak bid'i, dengan maksud tidak sesuai dengan sunnah dan tidak diizinkan oleh Allah. Asal kata bid'ah adalah sesuatu yang baru padahal sesuatu tersebut talah disempurnakan hukumnya ${ }^{56}$.

Kaitannya dengan ini, permasalahan talak telah ada gambarannya dalam al-Quran berikut dengan tata pelaksanaannya secara sempurna. Oleh kerana itu, maksud dan tujuan dari tidak dibenarkannya menceraikan isteri pada keadaan tersebut ialah salah satunya untuk tidak menyusahkan isteri dalam menentukan jenis iddah yang harus dilaksanakan. Kaitan dengan itu pula, menurut pendapat fuqaha, sebagaimana dikutip oleh Wahbah Zuhaili, bahwa terdapat ijma" mengenai dibolehkannya mentalak isteri dalam keadaan hamil, mengingat tidak ada kesulitan bagi kedua pasangan dalam menghitung masa iddah, dimana iddah wanita yang dicerai hamil dihitung hingga melahirkan anak.

Kekuatan hadis Ibn Umar dari aspek sanad dan matan serta sabab wurudnya seperti yang telah penulis bincangkan sebelum ini, dapat diterjemahkan sebagai ukuran yang jelas untuk membuktikan pendapat golongan jumhur ulama dalam kes talak isteri dalam keadaan haidh.

\footnotetext{
${ }^{53}$ Abdul Rahman al-Juzairi, Fiqh ala Mazahib al-Arba'ah, jld 5, hlm 617-631

${ }^{54}$ Sayyid Sabiq, Fiqh Sunnah, (terj: Asep Sobari, dkk), jilid 2, (Cet. II, Jakarta: Al-I’tishom, 2013) jld 2. H. 266

${ }^{55}$ Abdul Rahman al-Juzairi,Fiqh ala Mazahib al-Arba'ah, jld 5, hlm 617-631

${ }^{56}$ Wahbah al-Zuhaili, Fiqh Islam wa Adillatuhu: Pernikahan, Talak, Khulu', Ila', Li'an, Zihar dan Masa Iddah, (terj: Abdul Haiyyie Al-Kattani dkk), jilid 9, (Jakarta: Gema Insani, 2011), hlm 374-375.
} 
Berbeda dengan konstruksi hukum seperti tersebut di atas, dalam hal ini diwakili oleh pendapat Ibnu Qayyim al-Jauziyyah, beliau berpendapat bahwa suami tidak boleh menceraikan isteri dalam keadaan haidh, jika kemudian talak tersebut tetap dilakukan, hal ini tidak berlaku dan tidak dihitung sebagai talak, baik talak satu, talak dua dan seterusnya $^{57}$. Terhadap hal tersebut, laki-laki yang menceraikan itu dihukumi berdosa atas perbuatan yang dilarang dalam agama. Dalam hal ini, pendapat di atas mungkin sama seperti pendapat Ibnu Taimiyah (murid dari Imam Ahmad bin Hambal) yang notabene sebagai guru dari Ibnu Qaiyyim al-Jauziyyah. Walaupun demikian, tidak menutup kemungkinan adanya perbedaan terkait dengan alasan dan argumentasi serta metode yang digunakan oleh Ibnu Qayyim al-Jauziyah mengenai kedudukan talak seperti pada bahasan ini.

Klasifikasi hukum talak menurut Ibnu Qayyim terbahagi kepada dua bahagian, masing-masing talak tersebut iaitu talak yang haram dan halal. Perbuatan hukum talak yang dihukumi halal ketika suami menceraikan isteri saat suci dan pada saat suci itu lakilaki sebagai suaminya tidak menyetubuhi. Sedangkan kategori talak yang diharamkan iaitu menceraikan isteri ketika haidh, atau menceraikan isteri saat suci dan selama itu dia menyetubuhinya ${ }^{58}$.

Pada dasarnya, Ibnu Qayyim juga merujuk kepada dalil-dalil nas, terutama ayat alQuran yang berkaitan dengan ketentuan iddah sebagai alasan dan rujukan hukumnya. Terkait dengan hal tersebut, Ibnu Qayyim al-Jauziyyah menyatakan sebagaimana yang dikutip oleh Shalih bin Abdullah al-Lahim ${ }^{59}$, bahwa talak yang statusnya diharamkan tidak berlaku, serta tidak mungkin talak yang diharamkan dan dilarang dalam agama dianggap sah dan lazim keberadaannya. Ulama yang menilai talak bid'ah statusnya tidak sah, beralasan bahwa talak ini bertentangan dengan perintah Allah dan rasul saw. Sehingga talak ini tertolak, sebagaimana dinyatakan dalam hadis dari A'isyah ra, bahwa Nabi saw bersabda:

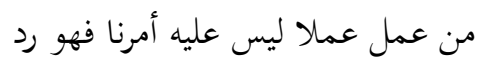

Artinya: "Siapa yang melakukan amalan yang tidak ada ketetapannya dari kami maka amal itu tertolak." HR. Bukhari dan Muslim

Dari hal ini, terdapat gambaran hukum bahwa sesuatu yang diharamkan terkhusus dalam masalah talak terhadap isteri saat haidh tidak dapat dijadikan status hukum sesuatu

${ }^{57}$ Ibnu Qayyim al-Jauziyyah, Mukhtashar Zā dul Ma'ad, (terj: Kathur Suhardi), (Cet. VI, Jakarta: Pustaka Azzam, 2005), h. 398.

${ }^{58}$ Ibnu Qayyim al-Jauziyyah, Mukhtashar Zā dul Ma'ad, (terj: Kathur Suhardi), (Cet. VI, Jakarta: Pustaka Azzam, 2005), h. 398.

${ }^{59}$ Shalih bin Abdulah al-Lahim, al-Ahkamal-Murattibah 'ala al-Haidhi wa alNifasi wa al-Istishadhati; Fiqih Darah Wanita, (terj: Nurul Mukhlisin), (Cet. II, Surabaya: Pustaka Elba, 2012) h. 272. 
yang sah dan talak tersebut dihukumi tidak jatuh. Artinya, suami masih memiliki jumlah talak hingga tiga kali jika pasangan suami isteri belum pernah bercerai. Perbezaan produk hukum tersebut secara sepintas terlihat sederhana, tetapi memiliki implikasi yang cukup besar bagi eksistensi dari pemberlakuan hukum talak. Implikasi dari dua model produk hukum ini akan menimbulkan paling tidak dua persoalan.

Pertama, perbedaan dalam mengartikan talak bid'i terkait dengan talak terhadap isteri yang sedang haidh. Sehingga berpengaruh pada berlaku atau tidaknya cerai yang dijatuhkan. Kedua, perbezaan dalam menganalisa hadis nabi serta perbedaan dalam memahami perbuatan dalam kategori "haram", apakah ada konsekuensinya atau tidak. Hal terakhir yang disebutkan juga berimbas pada kedudukan talak yang dijatuhkan.

Dalam masalah talak yang disyariatkan Allah dilihat dari segi waktu penjatuhan talak menurut Ibnu Qayyim adalah pada saat isteri dapat menjalankan masa Iddah. Dalam hal ini, talak yang sesuai menurut hukum syarak tersebut seperti talak dalam keadaan suci dan tidak digauli sebelumnya. Akan tetapi suami dilarang untuk mentalak isteri dalam keadaan haidh $^{60}$.

Seandainya talak bagi wanita haidh dijalankan, maka perintah untuk rujuk dan mentalak setelahnya adalah memperbanyak talak yang justru dibenci oleh Allah. Kemudian akan mengurangi jatah iddah yang menjadi kesempatan baginya untuk rujuk, serta hal yang demikian tidak ada maslahatnya ${ }^{61}$.

Ibnu Qayyim juga memberi komentar, sebagaimana dinukil oleh Shalih bin Abdullah al-Lahim, dengan penjelasan bahwa nikah tidak boleh terlaksana kecuali dengan kesungguhan dan keseriusan melalui ijab, qabul, wali dan dua orang saksi dan keredhaan isteri yang diperhitungkan. Sementara ia keluar (talak) dengan cara yang paling mudah. Ia tidak perlu keluar dengan cara seperti itu, ia masuk dengan azimah (keseriusan) dan keluar dengan syubhat. Ibnu Qayyim menjelaskan bahwa dalam Islam dibenarkan dan diterima tentang mudahnya keluar (talak) dari pernikahan. Namun, ia tidak boleh keluar darinya kecuali dengan apa yang dijadikan oleh Allah sebagai sebab yang boleh mengeluarkan darinya dan mengizinkannya. Adapun yang dibuat oleh manusia dan dianggapnya sebagai sebab yang boleh mengeluarkannya, maka hal itu tidaklah demikian ${ }^{62}$.

Pernyataan tersebut di atas dapat difahami bahwa keadaan haidh seorang isteri tidak boleh dijadikan sebuah kondisi dan sebab dijatuhkannya talak. Mentalak isteri dalam kondisi haidh merupakan sesuatu yang syubhat, artinya terdapat keraguan tentang status hukum talak tersebut. Kerana, tidak ada keterangan yang jelas mengenai dibolehkannya mentalak isteri dalam keadaan itu, baik dalam al-Quran maupun Hadis Rasulullah.

\footnotetext{
${ }^{60}$ Ibnu Qayyim al-Jauziyyah, Mawaridul Aman al-Muntaqa, h. 297.

${ }^{61}$ Ibnu Qayyim al-Jauziyyah, Tahzib Sunan Abu Daud., dikutip dalam Shalih bin Abdulah al-Lahim, al-AhkamalMurattibah, h. 269.

${ }^{62}$ Shalih bin Abdulah al-Lahim, al-Ahkamal-Murattibah 'ala al-Haidhi wa alNifasi wa al-Istishadhati; Fiqih Darah Wanita, (terj: Nurul Mukhlisin), (Cet. II, Surabaya: Pustaka Elba, 2012), h. 256.
} 
Namun, dalam Hadis telah diceritakan tentang talak yang dijatuhkan pada isteri yang sedang haidh, tetapi menurut Ibnu Qayyim Hadis tersebut bukan sebagi hujjah talak waktu haidh. Adapun Hadis tersebut iaitu: "Dari Ibnu Umar ia berkata, "Aku telah mencerai isteriku padahal ia sedang haidh." Lalu Umar menceritakan hal itu kepada Rasulullah saw, beliau lalu bersabda: "Perintahkanlah ia untuk merujuknya hingga kembali suci, kemudian haidh, kemudian suci, kemudian mencerainya sebelum ia mensetubuhinya kembali, atau tetap menahannya sebagai isteri jika ia mau, itulah iddah yang Allah telah perintahkan”. (HR. Bukhari).

Ibnu Qayyim menganalisis hadis tersebut dan menyatakan bahwa kata "ruju” dalam Hadis tersebut bukan merupakan istilah "ruju”" setelah terjadinya talak, melainkan dengan pengertian mufäalah ${ }^{63}$. Atau dalam kalimat lain bahwa suami yang mentalak isteri tersebut tetap kembali dengan sendirinya, tanpa adanya kata rujuk yang dikeluarkan oleh suami.

Selain itu, menurut Ibnu Qayyim, jika Hadis dari Ibnu Umar itu menunjukkan talak tersebut jatuh dan harus dirujuk, maka bertentangan dengan Hadis yang kualitasnya samasama sahih, yang juga diriwayatkan oleh Ibnu Umar. Diriwayatkan dari Ibnu Umar, bahwa seseorang telah mentalak isterinya dalam keadaan haidh, kemudian beliau berkata ia (wanita yang ditalak) tidak beriddah dengannya (tidak dianggap). Dari kedua Hadis yang diriwayatkan Ibnu Umar tersebut menunjukkan bahwa tidak ada nas yang jelas dari Rasulullah mengenai jatuhnya talak dan boleh beriddah dengannya. Apabila lafaz-lafaz tersebut saling bertentangan, maka menurut Ibnu Qayyim dikembalikan kepada fatwa ibnu Umar, Dimana, talak tersebut secara jelas tidak jatuh ${ }^{64}$.

Dari penjelasan tersebut, dapat difahami bahwa talak yang dilakukan atau dijatuhkan oleh seseorang terhadap isteri yang sedang haidh adalah tidak sah dan tidak jatuh menurut Ibnu Qayyim. Talak seperti ini tergolong sebagai talak yang diharamkan dan keluar dari aturan talak menurut al-Quran dan Hadis Rasulullah. Selain itu, talak tersebut tidak memiliki kemaslahatan bagi perempuan yang ditalak, apalagi iddahnya akan panjang dan tidak sesuai dengan bunyi firman Allah surah at-Thalaq ayat 1 yang mengharuskan seseorang mentalak isteri yang dapat menghadapi masa iddah secara wajar.

${ }^{63}$ Shalih bin Abdulah al-Lahim, al-Ahkamal-Murattibah 'ala al-Haidhi wa alNifasi wa al-Istishadhati; Fiqih Darah Wanita, (terj: Nurul Mukhlisin), (Cet. II, Surabaya: Pustaka Elba, 2012) h. 250

${ }^{64}$ Shalih bin Abdulah al-Lahim, al-Ahkamal-Murattibah 'ala al-Haidhi wa alNifasi wa al-Istishadhati; Fiqih Darah Wanita, (terj: Nurul Mukhlisin), (Cet. II, Surabaya: Pustaka Elba, 2012) h. 252-253. 
Secara ringkasnya, penulis cuba membezakan perselisihan pandangan antara mazhab jumhur dan Ibn Qayyim seperti berikut:

\begin{tabular}{|l|l|l|}
\hline $\begin{array}{l}\text { Mazhab } \\
\text { Ulama }\end{array}$ & Surah Al-Talaq Ayat:1 & Hadis Ibn Umar Ra \\
\hline Jumhur & $\begin{array}{l}\text { Talak waktu haidh menyalahi } \\
\text { tuntutan ayat, ia dianggap } \\
\text { bid'i, dan talak bid'i adalah } \\
\text { sah }\end{array}$ & $\begin{array}{l}\text { Perintah ruju' Rasulullah ke } \\
\text { atas Ibn Umar jelas } \\
\text { membuktikan talak telah } \\
\text { berlaku. }\end{array}$ \\
\hline $\begin{array}{l}\text { Ibn } \\
\text { Qayyim }\end{array}$ & $\begin{array}{l}\text { Talak waktu haidh menyalahi } \\
\text { tuntutan ayat, maka talak } \\
\text { tidak berlaku/tidak sah }\end{array}$ & $\begin{array}{l}\text { Rasulullah saw tidak } \\
\text { menyatakan talak itu jatuh } \\
\text { dan tidak pula menyuruh } \\
\text { anita yang ditalak untuk } \\
\text { beriddah }\end{array}$ \\
\hline
\end{tabular}

\section{PENUTUP}

Dari uraian dan penjelasan di atas, dapat disimpulkan bahawa matan hadis Ibn Umar ra yang menjadi fokus kes ini adalah jelas sahihnya. Para sanadnya adalah thiqat kesemuanya malah berstatus marfu' iaitu bersambung langsung kepada Rasulullah saw. Justeru perceraian yang dilakukan oleh suami ketika isterinya dalam keadaan haidh adalah haram dan berdosa secara sepakat ulama. Suami wajib menghormati hak isteri untuk mendapat keadilan sewajarnya dalam beriddah sesuai dengan firman Allah [65:1] seperti yang telah dijelaskan sebelum ini. Menzalimi isteri untuk berpanjangan dalam iddah adalah suatu dhirar atas isteri yang dilarang oleh Allah swt dan Rasulullah saw. Dari aspek keabsahan talak tersebut, ulama berbeda pandangan. Jumhur secara jelas mengambil kira talak tersebut sebagai sah, walaupun ada beberapa ulama antaranya Ibn Qayyim alJauziyyah memutuskan bahwa talak tersebut tidak sah. Dalam hal ini, pandangan jumhur ulama adalah yang rajih kerana selain dalil naqlinya yang kukuh, ianya lebih kepada menjaga maslahah terutamanya di pihak isteri agar tidak dizalimi tempoh iddahnya. Pandangan ini juga lebih aslah (amat baik) kerana ianya boleh memberi pengajaran kepada suami yang mempunyai kuasa talaq, agar menghormati isterinya yang mungkin ketika haidh mereka dalam situasi yang tidak sihat tubuh badan atau seumpamanya seterusnya mengelak suami menjatuhkan talaq hanya kerana mereka tidak mendapat layanan yang baik daripada isteri ketika sedang haidh. Talaq bukanlah suatu yang boleh dipandang remeh, hanya dengan sekali lafaz yang jelas serta soreh talaq adalah sah disisi syara' dan undang-undang.

Aturan dan adab dalam perceraian adalah suatu tuntutan dalam memelihara maslahah dan menjamin keadilan atas kaum wanita. Penindasan ke atas kaum wanita sering menjadi persoalan di kebanyakan negara Islam. perceraian dimungkinkan sebagai pintu akhir dalam rumahtangga yang tidak boleh dipertahankan, justeru rumahtangga yang 
sudah tidak harmonis lagi dan dipastikan tidak akan menemukan titik persamaan, cerai adalah menjadi jawabannya

Dengan khilaf dan perdebatan ilmiah para ulama dalam memahami matan hadis Ibn Umar, ianya dilihat sebagai satu kelonggaran dan rahmah untuk para hakim memutuskan keabsahan perceraian yang dilakukan ketika isteri dalam keadaan haidh. Hakim perlu melihat kepada maslahah kedua pihak suami dan isteri.

Di Malaysia, kes perceraian yang dilakukan di Mahkamah tidak akan diteruskan sekiranya isteri dalam keadaan haidh. Walaupun prosedur ini tidak tertulis dalam prosedur permohonan pembubaran perkahwinan (cerai) di bawah seksyen 47, Akta Undang-undang Keluarga Islam (AUKI) 1984, namun secara praktikal mahkamah mengamalkannya demi menjaga maslahah isteri.

\section{DAFTAR PUSTAKA}

Amir, Syarifuddin, Hukum Perkahwinan Islam di Indonesia; Antara Fiqh Munakahat dan Undang-Undang Perkahwinan, (Cet. III, Jakarta: Kencana Prenada Media Group, 2009).

Asqalani, Ibnu Hajar, Syihab al-Din ibn al-Fadhl Ahmad ibn Hajar. Tahzib alTahzib, (Beirut: Dar al-Kutub al-'Ilmiyyah, 1993).

Asqallaniy, Syihab al-Din ibn al-Fadhl Ahmad ibn Hajar, Tahzib al-Tahzib, juz V (Beirut: Dar al-Kutub al-'Ilmiyyah, 1993).

Awaysasyah, Husain Bin Audah, Al-Mausuah al-Fiqhiyyah al-Muyassarah Fiqh al-Kitab wa al Sunnah al-Muthahharah,(Beirut: Darul Hazm, 1973).

Azadiy, Al-Imam Abu Daud Sulaiman bin Àsy'as al-Sijistaniy. Sunan Abi Daud, (Suriah: Dar al-Hadis, 1970).

Bukhari, Al-Imam Abu Abdullah Muhammad bin Ismail Ibn Ibrahim bin Mughirah bin Bardizbah, Shahih al-Bukhari, Cet. I: Bairut-Libanon: Darul Kitab Ilmiyah, $1412 \mathrm{H} / 1992 \mathrm{M}$

Fathurrahman, Mustalahul Hadis (Bandung: al-Ma'arif, 1995).

Ismail, M. Syuhudi, Hadis Nabi Menurut Pembela, Pengingkar dan Pemalsunya (Jakarta: Gema Insani Press, 1995).

Ismail, M. Syuhudi, Kaedah Kesahiha n Sanad Hadis (Jakarta: Bulan Bintang, 1995).

Izz al-Din ibn al-Atsir Abu Hasan Ali ibn Muhammad al-Jaziriy, Usud al-Ghabat fi Ma'rifat al-Shahabah, Juz III (Beirut: Dar al-Fikr, t.th.) .

Jamal al-Din al-Hajj Yusuf al-Mizziy, Tahzib al-Kamal fi Asma al-Rijal, Juz XIX (Beirut: Dar al-Fikr, 1994). 
Jauziyyah, Ibnu Qayyim, Mukhtashar Zādul Ma’ad, (terj: Kathur Suhardi), (Cet. VI, Jakarta: Pustaka Azzam, 2005).

Juzairi, Abdul Rahman, Fiqh ala Mazahib al-Arba'ah, terj.Faisal Saleh, Cet:II, Jakarta: Pustaka al-Kautsar, 2017) .

Lahim, Shalih bin Abdulah, al-Ahkamal-Murattibah 'ala al-Haidhi wa al-Nifasi wa alIstishadhati; Fiqih Darah Wanita, (terj: Nurul Mukhlisin), (Cet. II, Surabaya: Pustaka Elba, 2012).

Mathlub, Abdul Majid Mahmud, al-Wajis fi al-Ahkam al-Islamiyah; Panduan Hukum Keluarga Sakinah, (terj: Harits Fadly, Ahmad Khotib), (Surakarta: Era Intermedia, 2005).

Mughniyah, Muhammad Jawad, al-Fiqh 'ala Mazahib al-Khamsah. Diterjemahkan oleh Afif Muhammad dengan judul Fiqh Lima Mazhab (Jakarta: Bulan Bintang, 1992).

Mughniyyah, Muhammad Jawad, Fiqih Lima Mazhab; Ja'fari, Hanafi, Maliki, Syafi'i, Hanbali, (terj: Masykur AB, dkk), (Cet. XVIII, Jakarta: Lentera, 2006).

Muttaqin, Ulumul Hadis (Yogyakarta: Titian Ilahi Press, 1997).

Nasa'i, Sunan al-Nasa’i, (Beirut: Dar al- Fikr, t.th).

Nawawiy, Shahih Muslim bi Syarh al-Nawawiy (Beirut: Dar al-Fikr, 1978).

Nur al-Din Itr, Manhaj al-Naqd fi Ulum al-Hadis. Diterjemahkan oleh H. Endang Soetari dan Mujiyo dengan judul Ulum Al-Hadis I (Bandung: Remaja Rosdakarya, 1995).

Sabiq, Sayyid, Fiqh Sunnah, (terj: Asep Sobari, dkk), jilid 2, (Cet. II, Jakarta: Al-I"tishom, 2013).

Sarong, Hamid, Hukum Perkahwinan Islam di Indonesia, (Cet. III, Banda Aceh: Yayasan PeNA, 2010).

Subhan, Zaitunah, Menggagas Fiqh Pemberdayaan Perempuan, (el-Kahfi, Jakarta, 2008).

Tahhan, Mahmud, Taysir Mushttalah al-Hadis. Diterjemahkan oleh Zainul Muttaqin dengan judul Ulumul Hadis (Yogyakarta: Titian Ilahi Press, 1997).

Turmuzi, Abu Isa Muhammad bin Isa as-Sulami at-Turmuzi, Sunan al-Tirmizi.

Umbara, Citra, Undang-Undang Republik Indonesia Nomor 1 Tahun 1974, Perkahwinan dan Kompilasi Hukum Islam, (Cet. V, Bandung: Citra Umbara, 2014).

Usaimin, Muhammad ibn Shalih, Fi al-Dima' al-Tabi'iyah li al-Nisa'. Diterjemahkan oleh Muhammad Yusuf Harun dengan Judul Darah Kebiasaan Perempuan (Jakarta: Akafa Press, 1997).

Zuhaili, Wahbah, Fiqh Islam wa Adillatuhu, (terj: Abdul Haiyyie Al-Kattani dkk), (Jakarta: Gema Insani, 2011). 